\title{
PEASANTS' LAND RIGHTS CLAIMS OVER PLANTATION COMPANIES' SITES IN CENTRAL JAVA, INDONESIA (1998-2014)
}

\author{
Siti Rakhma Mary Herwati* and Yanuar Sumarlan***
}

\author{
* President University and Member of Public Interest Lawyer Network (PILNET). \\ ** Institute of Human Rights and Peace Studies, Mahidol University, Thailand.
}

\begin{abstract}
Article Info
Received : 28 September 2015 | Received in revised form : 3 April 2016 | Accepted : 26 April 2016

Corresponding author's e-mail : rahma.mary@gmail.com ; yanuar.sum@mahidol.ac.th
\end{abstract}

\begin{abstract}
This article reveals the opening of political and legal opportunities for the landless peasants of Central Java at the end of the 1990s to reclaim their lands that were confiscated during the end of the 1950s through a nationalization program to take over Dutch-controlled lands. Taking two sites of plantations that have been targeted as the peasantries' land reclaiming campaign, this article shows the processes of the reclaiming, the responses of both plantation companies and state, and the respect of the state over rights to access lands or property rights of the peasants as citizens. Using some legal and anthropological approaches, this article finds that the statethrough its apparatuses in business units, legal enforcement agencies, government units, courts, etc-is trapped in a Stocksian Paradox that is worse than its original Latin American version because the state has a deep conflict of interest as one of the "counter-claimants" of the indigenous or peasantries' claim to rights to property/land. The authors recommend that although a robust civil society representing the peasantries is one of important parts in rights-reclaiming campaigns, the deeper Stocksian Paradox remains the biggest stumbling block in fulfilling state's roles as rights-givers to its citizens.
\end{abstract}

Keywords: peasant resistance, state response, fulfillment, land rights

\begin{abstract}
Abstrak
Artikel in menunjukkan terbukanya peluang-peluang politis dan hukum bagi petani tak bertanah di Jawa Tengah di penghujung tahun 1990-an untuk menuntut kembali tanah mereka yang pernah dirampas pemerintah di akhir tahun 1950-an selama program nasionalisasi atas tanahtanah yang dikuasai perusahaan perkebunan atau orang-orang Belanda. Melalui naratif di dua lokasi perkebunan yang dijadikan tempat penuntutan kembali tanah oleh para petani tak bertanah, artikel ini merunut kembali proses penuntutan kembali tanah, reaksi perusahaan perkebunan dan negara, dan penghormatan negara atas hak konstitusional warga negara atas hak atas tanah atau properti. Dengan pendekatan legal dan antropologis, artikel ini menemukan bahwa negara-lewat aparat berwujud unit-unit usaha, badan-badan penegakan hukum, unitunit pemerintahan lokal, pengadilan, dan lainnya - telah terjebak dalam Paradox Stocksian yang ternyata lebih buruk daripada versi aslinya di Amerika Latin karena negara terjebak dalam konflik kepentingan yang sulit sebagai satu dari pemain dalam perebutan hak atas tanah. Penulis menyimpulkan bahwa meskipun masyarakat sipil yang kuat mewakili kepentingan warga negara atau petani tak bertanah sangatlah penting dalam usaha-usaha penuntutan kembali hak atas tanah, Paradox Stocksian tetaplah menjadi bantu sandungan terbesar bagi negara untuk memenuhi hak-hak konstitusional warga negaranya.
\end{abstract}

Kata kunci: perlawanan petani tak bertanah, reaksi negara, pemenuhan hak, hak atas tanah 


\section{Introduction}

This article aims to reveal a possibility that the state fails to respect, protect, and remedy some forms of human rights violation against peasants in Central Java, Indonesia. States have obligation to respect, protect, and to fulfill human rights. As a consequence, the states and its authorities must implement those obligations to respect the rights accepted, for example, freedom of religion which is categorized as civil and political rights. The other implementation that must be carried out are obligations in the area of economic, social, and cultural (ECOSOC) rights. The implementation of the economic, social, and cultural rights means a positive activity of fulfillment by the state, for example, to grant or to provide certain services like education, health, food, and housing to ensure certain minimum standards. ${ }^{1}$

In order to do so, this paper will elaborate two cases of plantation land conflicts, starting with background of the research, the root of land conflicts, and the history and causes of the land conflicts. This article also elaborates the cases through description of the cases, recent condition of the cases, and the state responses to cases which contain some actions after the courts' verdicts favor the peasants.

The authors select two sites in a multiple case study design and use various techniques to acquire data for this study such as interviews and oral history (the history of plantation lands, the reclaiming actions/process, the peasants' resistance, and the state responses). The researchers also conducted observation on those villages and plantation lands to understand the recent condition of the plantation lands and to observe the peasants' access to the lands after the courts' verdicts. In order to understand the state responses through Courts and its result, the researcher gathered all documents during the litigation process in the Courts.

The methods and findings of this research are intended to help growing expertise for the study of law which can draw upon social science methods to enrich and deepen the study of law. This study will be contributing to scholarship on the challenge of compliance with international norms and/or international human rights laws that are posed by domestic legal and political institutions and practices.

\section{Land Conflicts: Recent Situation in Indonesia}

Indonesia began the year of 2014 with the death of a member of Anak Dalam tribe by the security apparatuses in Jambi Province, Sumatera, in land conflict between Anak Dalam tribe against Asiatic Persada Company. Another case is the burning of houses of a community in Riau province, Sumatera by the military forces, police forces, and thugs in land conflict area of Arara Abadi Company. ${ }^{2}$ In Java, land disputes between state plantation companies and peasants also happen. In March 2014, three peasants were arrested and jailed for 1.5 year in Sragen District, Central Java in a land dispute between peasants and state plantation company (PTPN) IX Sambirejo. This case is one of approximately 50 structural agrarian conflicts in Central Java which involve state plantation companies (PTPN), private plantation companies, and state forest company (Perhutani).

\footnotetext{
1 Wolfgang Benedek, ed., Understanding Human Rights: Manual on Human Rights Education, (Graz: European Training and Research Centre for Human Rights and Democracy (ETC), 2012), p. 43.

2 Suara Pembaruan, "Aparat Gabungan Hancurkan Rumah Warga di Siak," http://www.suarapembaruan.com/nasional/aparat-gabungan-hancurkan-rumah-warga-di-siak/51862, Accessed 27 March 2014.
} 
Those cases are just the tip of the iceberg of similar unresolved cases throughout Indonesia. Those land disputes show that structural agrarian conflicts in Indonesia are still existing and increasing. From 2012 to 2014, a number of land conflicts exploded in some places and some were accompanied by violence. The Association for Community Based and Ecological Law Reform (HuMa) reports 278 structural agrarian conflicts in 23 provinces. The Agrarian Renewal Consortium (KPA) has compiled 472 land disputes during 2014 covering around 2.86 million ha of land. These conflicts produced 19 deaths, 17 people shot, 110 people tortured, and 256 farmers detained. ${ }^{3}$ These conflicts occur between farmers or indigenous peoples on the one hand, and private plantation companies, private forest companies, state forest company, private mining companies, or local/national government units on the other. The National Human Rights Commission conveyed that the biggest number of complaints received by the Commission in 2012 was land dispute which reached up to 399 cases. ${ }^{4}$ Likewise, agrarian conflict was the highest sector that produced most complaints in $2013 .{ }^{5}$ These conflicts occured between farmers or indigenous peoples on the one hand, and private plantation companies, private forest companies, state forest company, private mining companies, or local/national government units on the other hand.

Land disputes between peasants and plantation companies have been reoccurring since 1957 when Sukarno's Old Order conducted the nationalization policy and in 1965 when farmers who cultivated their farms were accused as members or followers of the Indonesian Communist Party. They did not have access to their lands since those periods. The situation of farmers, peasants, indigenous peoples, and local community such as Anak Dalam tribe was getting worse when the new government under President Susilo Bambang Yudhoyono (2004-2009, 2009-2014) continued to issue many legal permits to plantation companies, forest industries, and mining companies. In Java, some companies' certificates of right of commercial cultivation (Hak Guna Usaha/HGU) which had expired in the 2000s were extended by the government.

The end of the 1990s or 1998 was an era when peasants found momentum to reclaim their lands. The state was weakened at that time because of the fall of General Suharto. Peasants used the opportunity to reclaim their lands. Many reclaiming actions happened in some villages particularly in Java, Sumatra, and Celebes. Most of those reclaiming actions had returned the lands back to the peasants. But, the government never let it go as it was. It responded through various ways such as criminalizing the peasants, hiring thugs, suing the peasants to court, facilitating negotiation, or proposing an agrarian reform program.

In Central Java, the reclaiming actions happened in some villages in several districts such as Kendal, Batang, Pati, Semarang, Banyumas, and Cilacap. The Semarang Legal Aid Institute (LBH Semarang) which handled some cases on land disputes revealed the increase in number of criminalization against peasants in Central Java since 1998 as well as the number of cases in court as the result of the reclaiming actions.

${ }^{3}$ KPA (Konsorsium Pembaruan Agraria) [Agrarian Renewal Consortium], "Laporan Akhir Tahun KPA," http://www.kpa.or.id/wp-content/uploads/2011/11/Laporan-Akhir-Tahun-2013-KPA final-release-19Des.pdf, accessed 5 April 2014.

4 Komnas HAM. "Catatan HAM 2012 dan Rekomendasi. Saatnya Merajut Toleransi dan Kohesi Sosial," http://www.komnasham.go.id/siaran-pers/catatan-ham-2012-dan-rekomendasi, accessed 16 May 2015.

${ }^{5}$ Komnas HAM. "Pandangan Komnas HAM terhadap Situasi Hak Asasi Manusia Tahun 2013 dan Tantangan Pada 2014," http://www.komnasham.go.id/sites/default/files/dokumen-siaranpers/Catatan\%20Awal\%20Tahun\%20 Komnas\%20HAM.pdf, accessed 16 May 2015. 
However, the repressive response of the local government was followed by positive actions such as some negotiations which were facilitated by the government to solve the land disputes, court's verdicts, and the issuance of land reform program by the government.

In this research, two sites are chosen to find out whether the state's responses to land conflict in Central Java correspond to its obligation to fulfill citizens' rights to property. Those sites are: Kalidapu Village (Singorojo Sub-district, Kendal District, Central Java in plantation land dispute between peasants and a state plantation company-Perseroan Terbatas Perkebunan Negara Nusantara IX) and Tumbrep Village (Bandar Sub-district, Batang District, Central Java in plantation land dispute between peasant and a private plantation company named P.T. Tratak.

These cases were the only two structural plantation land cases in Central Java where plantation companies had lost in administrative and civil court processes. There are many cases during 2000-2014 where peasant lost at district courts (criminal and civil cases) and administrative court. The Table 1 below shows these cases.

Table 1: Peasant Versus Plantation Companies in Court

\begin{tabular}{|c|c|c|c|}
\hline Case & Court & Year & Status \\
\hline $\begin{array}{l}\text { Peasant versus PT } \\
\text { Pagilaran, Batang } \\
\text { District }\end{array}$ & $\begin{array}{l}\text { Criminal Case in the } \\
\text { District Court }\end{array}$ & 2000 & District Court: Peasants Lost \\
\hline $\begin{array}{l}\text { Peasant versus PT } \\
\text { Pagilaran, Batang } \\
\text { District }\end{array}$ & Administrative Court & $2008-2011$ & Supreme Court: Peasants Lost \\
\hline $\begin{array}{l}\text { Peasant versus PT KAL, } \\
\text { Kendal District }\end{array}$ & $\begin{array}{l}\text { Criminal Case in the } \\
\text { District Court }\end{array}$ & 2008 & District Court: Peasants Lost \\
\hline $\begin{array}{l}\text { Peasant versus PT KAL, } \\
\text { Kendal District }\end{array}$ & $\begin{array}{l}\text { Criminal Case in the } \\
\text { District Court }\end{array}$ & 2008 & $\begin{array}{l}\text { District Court: Peasants Lost } \\
\text { High Court: Peasants Lost } \\
\text { Supreme Court: Peasants Won }\end{array}$ \\
\hline $\begin{array}{l}\text { Peasant versus PT KAL, } \\
\text { Kendal District }\end{array}$ & Administrative Court & 2010 & Province Court: Peasants Lost \\
\hline $\begin{array}{l}\text { Peasant versus PT } \\
\text { Sinar Kartasura, } \\
\text { Semarang District }\end{array}$ & $\begin{array}{l}\text { Criminal Case in the } \\
\text { District Court }\end{array}$ & 2000 & District Court: Peasants Won \\
\hline $\begin{array}{l}\text { Peasant versus PT } \\
\text { Sinar Kartasura, } \\
\text { Semarang District }\end{array}$ & $\begin{array}{l}\text { Criminal Case in the } \\
\text { District Court }\end{array}$ & 2001 & District Court: Peasants Lost \\
\hline $\begin{array}{l}\text { Peasant versus PT } \\
\text { Sinar Kartasura }\end{array}$ & Administrative Court & $\begin{array}{l}2001- \\
\text { present }\end{array}$ & $\begin{array}{l}\text { Province court: Peasants Lost } \\
\text { High court: Peasants Lost } \\
\text { Supreme Court: Peasants Won }\end{array}$ \\
\hline $\begin{array}{l}\text { Peasant versus PTPN } \\
\text { IX, Pekalongan District }\end{array}$ & $\begin{array}{l}\text { Civil Case in the } \\
\text { District Court }\end{array}$ & 2006 & District Court: Peasants Lost \\
\hline $\begin{array}{l}\text { Peasant versus PT } \\
\text { Rumpun Sari Antan }\end{array}$ & $\begin{array}{l}\text { Criminal Case in the } \\
\text { District Court }\end{array}$ & 2001 & District Court: Peasants Lost \\
\hline $\begin{array}{l}\text { Peasant versus PTPN } \\
\text { IX, Sragen District }\end{array}$ & $\begin{array}{l}\text { Criminal Case in the } \\
\text { District Court }\end{array}$ & 2014 & District Court: Peasants Lost \\
\hline
\end{tabular}

Source: LBH Semarang documents 
The different kinds of the government reaction to respond to the structural land conflicts raises question: Has the government fulfilled peasants' right to land when courts' verdicts favor the peasants? The researchers took two cases into a multiple case study design to understand the process on land confiscation, peasant resistance, the state responses, and the state responses in connection with fulfillment of the peasants' rights to land.

\section{The Root of the Land Conflicts}

The PTPN IX appeared in 1957 when the Indonesian government conducted the nationalization policy. This policy nationalized all of the Dutch/foreign assets such as plantations, houses, or buildings to be under Indonesian government's control. In Kalidapu village, the nationalization wreaked havoc to the peasants because their lands were taken over by the government to become state plantation. Peasants in Kalidapu village had opened the land forest in the 1930s and cultivated the lands with crops. The land conflict between peasants and the PTPN IX began in 1957 when peasants in Kalidapu village received a warning letter from the state plantation company barring peasants' access to their own lands. ${ }^{6}$ The letter was signed by the military authority, the local government, and the company's representative. It stated that peasants had occupied the lands illegally according to the War-time Local Authority Regulation (Peraturan Penguasa Perang Daerah/Peperda) 1957; ${ }^{7}$ therefore, the peasants must leave the lands. Since then, the peasants lost their lands which were suddenly taken over by the PTPN IX. The company planted rubber and coffee on the plantation land.

Land conflict between peasants and PT Tratak began in 1957-1959 when the peasants were evicted from their lands which they had cultivated since 1945. In the 1930s, the lands were owned by a Dutch company. The Peasants called the Dutch owner as Mrs. Mitha. After the Japanese occupation (1942-1945), the peasants returned to their lands which had previously been destroyed by the Japanese Imperial Army. However, their activity did not last long because the Indonesian military retook peasants' lands and put it under its authority in $1957 .{ }^{8}$

There is similarity related to the period of the land confiscation (1957-1959). The land confiscation occurred when the nationalization policy was implemented. During that period, the Sukarno's Old Order regime handed over parts of its authority to the Army as the government declared the state of emergency. That situation enabled the military to run some policies including taking over peasants' lands.

In the case of PT Tratak, after the military took over the peasants' lands, the lands were handed over to PT Perusahaan Perkebunan Tratak (Tratak Plantation Company) which was established in 1958. Led by its first Director Jap Kim Loan, the company planted rubber and coffee on the 89.94 ha of land and obtained its right of commercial cultivation land certificate (Hak Guna Usaha or HGU) No. 1/1988. Approximately half of the plantation lands ( $40 \mathrm{ha}$ ) outside of the main plantation area was rented to the peasants of Kambangan and Wonomerto Hamlets. ${ }^{9}$ The peasants cultivated the rented lands with corn and cassava, but they had to give one third of their crop yields to

\footnotetext{
${ }^{6}$ Interview with S (74), a peasant from Kalidapu Village, Kendal, 31 August 2014.

7 Letter No. PER/1957, June 1957, issued by Penguasa Perang Daerah (The War-Time Local Authority).

${ }^{8}$ Interview with A (89), a peasant from Cepoko Hamlet, Tumbrep Village, Batang, 27 August 2014.

9 Interview with A, T, D, peasants from Cepoko Hamlet, Tumbrep Village, Batang District, 25 August 2014.
} 
the company. ${ }^{10}$ This cultivation model occurred in the early 1960 s until 1998, but things worsened after Jap Kim Loan passed away and left the plantation to his son Jap Yok Jwan. Under new direction, the management of the plantation company declined. In the end of 1970s, for example, the plantation land was abandoned, and social conflict occurred in the surrounding villages. In 1987-1988, Jap Yok Jwan loaned the plantation land to PG. Cepiring (Cepiring Sugar Company) that planted sugarcane. This sub-contract on the plantation land was continued in 1989-1990 between PT Tratak and PG. Sragi (Sragi Sugar Company). After the sub-contract finished, PT Tratak cut down all rubber trees in 1989-1990 without replanting the land. As a result, the land was largely abandoned and became wild boar's nest. ${ }^{11}$ Realizing that it could not manage the plantation, PT Tratak allowed the peasants to use the lands in exchange of submitting one third of their crop yields to the company, some money, voluntary labor to maintain the plantation land, and voted for the government's Golkar Party in every legislative election. The peasants must follow this arrangement otherwise they could not use the lands. ${ }^{12}$

Conflict exploded in 1998 when one of PT Tratak's foremen persecuted a peasant who was accused for not paying his land rent. This incident triggered the demolition of the foreman's house and the demand by the peasants to the company to return the plantation land back to the peasants.

\section{1998: A Momentum to Reclaim Land}

The resistance in 1998 had started with the so called "reclaiming land action". In these cases, the reclaiming action were not run by the peasants themselves but by support and involvement of some other parties such as the Indonesian Legal Aid Foundation (YLBHI) through its branch the Semarang Legal Aid Institute and some local lawyers. The involvement of the Semarang Legal Aid Institute in assisting the peasants was part of the YLBHI's strategy after observing political situation of Indonesia since 1996. YLBHI contributed to play a significant role to what Aspinall ${ }^{13}$ said as "undermining the ideological foundations of authoritarian rule." Aspinall ${ }^{14}$ included the YLBHI as the third category of civil society that emerged after the New Order's first decade which was called proto-oppositional civil society organizations. Aspinall ${ }^{15}$ identifies that kind of organization "strove to maintain greater autonomy from state intervention and sometimes adopted a critical stance toward state policies and actions. They mostly avoided repression by emphasizing particularistic goals rather than pushing for systemic change."

The peasants in these cases established their local peasant organization, collected data, initiated peasants discussion, built network with NGOs, lawyer, and university students, and started to lobby the local government and Land Institution Agency to

\footnotetext{
${ }_{10}$ Peasants called this cultivation type as "mertelu" (two third of the crop yields for peasants, and one third given to the company).

11 Interview with A, T, D, peasants from Cepoko Hamlet, Tumbrep Village, Batang District, 25 August 2014 and interview with $\mathrm{H}$, a peasant lawyer in Cepoko Hamlet, 26 August 2014.

12 Conflict chronology of PT Tratak, a document composed by FPPB, no year.

${ }^{13}$ Edward Aspinall, "Transformation of Civil Society and Democratic Breakthrough" in Civil Society and Political Change in Asia, Expanding and Contracting Democratic Space, edited by Muthiah Alagappa, (California: Stanford University Press, 2004), p. 63.

${ }^{14}$ Ibid.

15 Ibid.
} 
gain support or to get recommendation letter in order to strengthen their resistance. Through lobbies, peasants in Kalidapu village secured supporting letters from a local parliament's commission (Komisi A DPRD Kendal) to cultivate/access the plantation land. The letter strengthened the peasants who reclaimed lands by staking and planting the lands after getting the letter. They distributed the lands to their peasant members who joined a local peasant organization called Kerukunan Warga Kaliputih/ KWK (United Kaliputih Farmers) and cultivated the lands with crops and paddy. This local organization was later supported by the local peasant organization at the district level called Forum Persaudaraan Petani Kendal (Kendal Farmer Brotherhood Forum) which was established on 4 August 2002.

For the peasants in Batang District, the "reformasi" strengthened the resistance that had started since 1988 by cultivating the abandoned lands. After they destroyed the foreman's house, they started to make this movement visible by contacting a local lawyer in the village. At the same time, the Semarang Legal Aid Institute also offered legal aid to the peasants after learning about this case from a local newspaper. Supported by the Semarang Legal Aid and an individual lawyer, 425 peasant households established a local organization called Paseduluran Petani Penggarap Perkebunan Tratak/P4T (Tratak Plantation Peasant Brotherhood). The struggle of the peasants gained more support when the local peasant organization called Forum Perjuangan Petani Batang (Struggle Forum of Batang Farmer) which supported the struggle of P4T changed its name to Omah Tani (Farmer House) and solidify its activities in 2009.

\section{The Companies' and the State's Responses}

In the case of PTPN IX, the state responded to the reclaiming actions by criminalizing the peasants' action in a series of short-lived attempts. Thereafter, the government tried suing the peasants to courts for illegal occupation over lands of the plantation. The civil court had started in 2000 and the first court process took two years before the verdict was reached. The peasants were lost at the lower court; thus they appealed to the High Court in Central Java. Unfortunately, the High Court's verdict strengthened the decision of the lower court. Amid their disappointment, the peasants appealed against this decision to the Supreme Court in 2003. In 2010, the Supreme Court decided that the PTPN IX lost to the peasants.

During 2002-2014, some incidents occurred in the land conflict area. For example, the plantation company's workers cut or destroyed thousands of the peasants' banana trees in 2007. ${ }^{16}$ Such actions had also been repeated several times and there were no clear responses from the police when peasants complained the criminal actions. Once, the peasants filed complaint to the police, and this case had been brought to court. The judges decided the perpetrators as guilty, but they punished the perpetrators only with probation with light jail term.

The case of Tratak Plantation (Company) started in 1998 when the peasants reclaimed the abandoned land of the company. The idle status of the plantation company did not hamper the company to counter the peasants' action. The government at the local and provincial level initiated to solve this case by facilitating

16 Kendalonline, “Tanaman tumpangsari dibabat PTPN IX Warga Banyuringin protes,” http://www. kendalonline.net/2007/04/10/tanaman-tumpangsari-dibabat-ptpn-ix-warga-banyuringin-protes/, accessed 13 September 2014. 
negotiation between the peasants and the company. The negotiation failed because the plantation company did not agree to release a part of the land to the peasants. This case began to favor the peasants when President Yudhoyono and Head of the National Land Agency (Badan Pertanahan Nasional/BPN) Joyo Winoto launched a land redistribution program called Reforma Agraria in January 2007. The program planned to redistribute 1.10 million hectares of state lands under the authority of the National Land Agency and 8.15 million hectares of forest lands under the jurisdiction of the Ministry of Forestry. The National Land Agency also identified 7.30 million hectares of abandoned lands to be redistributed. ${ }^{17}$

Related to that policy, the case of PT Tratak has been included by the government as one of the plots for agrarian reform. In 2010, the National Land Agency started to investigate the case, noted, and decided the legal status of the plantation. In 2013, the National Land Agency issued a letter of decision which stated that the PT Tratak plantation had abandoned their land and therefore their land certificate was revoked. PT Tratak company resisted the decision and sued the National Land Agency to the Administrative Court to cancel the decision. In 2013, the court decided that the National Land Agency was on the right way; the plantation company lost the case.

\section{The Cases}

\section{A. Tratak Plantation (Company)}

Despite the Courts' decision to the peasants' favor, whether the state had fulfilled the peasants' right to land or not remained a question. It seems that the state/the government takes its responsibility to fulfill peasants' right to land by revoking the rights or land titles of commercial cultivation (HGU) PT Tratak in 2013. Nevertheless, the process to revoke the plantation's land rights takes a long procedure. Since the cases exploded in 1998, the peasants have complained to the government for more than three times, especially to the National Land Agency at the provincial level to revoke the right of commercial cultivation. However, this action has not achieved much attention from the National Land Agency and the Governor. The provincial government formed a government team to identify and solve land cases in Central Java including the plantation land of PT Tratak in 2002. This initiative was taken as a response to peasants' large demonstration in front of the Central Java Governor Office in 2002 to urge the government to solve structural land cases in Central Java. But the existing team has never made any significant progress except accommodating the peasants' demands and conducting field observation over the plantation land of PT Tratak. The existing regulation on Abandoned Land (President Regulation No. 36/1998 concerning The Control and Utilization of Abandoned Land) has never been really implemented. In this regulation, government can take several steps after accepting complaints from citizens when they have information about abandoned lands; for example, when a plantation company has been warned for three times to ulitilize their plantation lands. If the company refuses to do so, the government can revoke its land right, put the lands under "abandoned land" status, and retake the lands under state lands status. In 2004, the Batang Regent initiated a letter of recommendation to revoke PT Tratak's right of commercial cultivation. Normally the letter should be

17 Noer F. Rachman, “The Resurgence of Land Reform Policy and Agrarian Reform in Indonesia," (A dissertation submitted in partial satisfaction of the requirements for the degree of Doctor of Philosphy in Environmental Science, Policy and Management, University of California, Berkeley, 2011). 
followed up by the National Land Agency to begin identifying, warning, and taking action to revoke the plantation company's land right. However, no other action is taken after these series of action. This hanging situation escalates social conflict at the grassroot level; for example, during 2007-2008 PT Tratak hired thugs to intimidate the villagers, the peasants and their lawyer. In 2008, the local police also summoned 21 peasants to be interrogated after the police received complaints from PT Tratak about the peasants' land occupation. ${ }^{18}$

The National Land Agency's action to revoke the plantation land just began in 2011 after the government issued Law No. 11 Year 2010 regarding The Control and Utilization of Abndoned Land. This law replaced the previous law on abandoned land (President Regulation No. 36/1998). Based on this law, the National Land Agency started to identify and warn PT Tratak to utilize their plantation land. The warning letters were delivered three times (13 May 2011, 14 June 2014, and 15 July 2014), however according to the National Land Agency there were no effort to plant and utilize the land done by PT Tratak. ${ }^{19}$ Therefore, the National Land Agency issued a Decision Letter No. 7/PTT-HGU/BPN RI/2013 dated 16 Januari 2013 concerning the Abandoned Land Determination of HGU No.1/Batang owned by PT Tratak.

Resisting the National Land Agency's decision, PT Tratak sued this institution to the Jakarta-based Administrative Court. PT Tratak as plaintiff demanded the Court to cancel the decision. The suit was registered by the Court through case registration No. 25/G/2013/PTUN-Jkt. This lawsuit was known by the peasants which intervened the court examination process by sending a letter of application to the Court's judges to determine them to be the intervenient in this case. ${ }^{20}$ This application was agreed by the judges, and the peasants were involved as a party in this law suit case as tergugat intervensi (intervenient defendant). Some public interest lawyers based in Jakarta provided legal aid and represented the peasants in the Court. PT Tratak was represented by a lawyer who is also a Chairman of State Plantation Worker Union.

During the court process, it became known that the National Land Agency did not have any important documents related to the land case. Most of the documents were provided by the peasants, such as government letters and results of peasants' hearing forums which showed the process of resolving the plantation land case. In order to defend their rights, the intervenient defendant have also presented four witnesses including experts to tell facts about the plantation land and the Indonesian Agrarian Law. These efforts was null from the plaintiff (the company) and the defendant (the National Land Agency) because they presented no witness at all.

After three months through the court process, the judges rejected the plaintiff's demand. The judges' verdict considered that the process to revoke the right of commercial cultivation was the right procedure; it was already based on the existing regulation. However, the history of the plantation land and the peasants' land rights were not considered by the judges in their verdict. As there was no appeal from PT Tratak to respond to the verdict, the verdict could be executed. The problem now is the implementation of land redistribution as a part of agrarian reform program conducted by the National Land Agency.

Two months after the Court's verdict, the National Land Agency's officials at

18 Interview with T, a peasant from Cepoko Hamlet, 25 August 2014, and H, a peasant lawyer from Cepoko Hamlet, 27 August 2014.

19 Jakarta Administrative Court, “Decision No. 25/G/2013/PTUN-Jkt,” p. 36.

20 "Intervenient" is involved third party in Administrative Court to defend his interest. 
the provincial level visited Cepoko Hamlet to observe the plantation land current condition. When the officials spent time for dialogue with the peasants, the former promised to redistribute the ex-HGU of PT Tratak in fiscal year $2015 .^{21}$

In December 2014, the Central National Land Agency sent a letter to the Province concerning the Utilization of Land Ex HGU No. 1 Batang in the name of PT Perkebunan Tratak. The National Land Agency classified the land under General Reserves of State Land (Tanah Cadangan Umum Negara). Head of the Central National Land Agency asked the Head of the Province National Land Agency to coordinate with the government units of Batang District to plan and follow up the allotment of the land of 79.84 ha which will be ulitized by the community and of 10 ha for the state reserves. For that plan, the community will obtain communal land certificate to give opportunity for the farmers/beneficiaries to cultivate the land actively and prevent land transfer for those who abandoned the land. Meanwhile, the other reserves of land will be given a land title when the government composes a proposal containing detail of cost or budget of the development plan.

For the first allotment (Agrarian Reform for land of 79.84 ha), the Central National Land Agency requested the Province National Land Agency to prepare a list containing beneficiaries of the Agrarian Reform who joined a farmer organization called "Omah Tani" and their citizen identity cards. Secondly, the Province National Land Agency was assigned to prepare a siteplan containing roads, social facilities, public facilities, and agricultural allotment. Through the letter, the National Land Agency used the former ex-plantation land of PT Tratak as object of the Agrarian Reform Program.

On February 11, 2016, the Minister of Agrarian and Spatial Planning finally redistributed around 75,6 hectares of the land to the 425 peasant households. The Minister claimed that the redistribution was part of the government's program on Agrarian Reform. ${ }^{22}$

\section{B. The PTPN IX}

Despite supports by District Parliament's Commission, reclaiming actions by the peasants in Kalidapu village faced another resistance because the state plantation company filed a lawsuit against peasants to Court. About 520 peasants had been sued in the District Court and been registered with the case number of 16/Pdt.G/2000/ PN Kdl. The Plaintiff claimed that the peasants had been illegally occupying the plantation lands of the PTPN IX or committed unlawful act. It demanded the judges to declare that the lands belong to the PTPN IX and to require the peasants to pay some compensation to the Plaintiff (the PTPN IX) for its financial losses because of the peasants' illegal occupation. The Semarang Legal Aid Institute had delivered legal aid for the peasants by representing 25 peasants as their lawyer in the Court and assisted others (495 peasants/defendants) who gave mandate letters to other peasants/defendants. The legal aid institution had trained the peasants, especially

21 Interview with H (lawyer), Cepoko, Batang, 26 August 2014.

22 In 2016, the Minister of Agrarian and Spatial Planning under President Jokowi's Cabinet redistributed hundreds hectares of lands in some villages in Java and Sumatra. However, the land redistribution cannot be seen as the genuine agrarian reform because this action does not really solve the larger problem of massive land grabbing. The number of land redistributed was very small, covering only few hundreds of hectares of about 16.55 million hectares of land which were promised by the previous Susilo Bambang Yudhoyono's government to be redistributed (Rachman, 2011). Moreover, the robust design of the Agrarian Reform and the correlation among sites where the redistributions have taken place are not clear. This program is turning to be a merely ceremonial certification of land in a manner of business as usual program conducted by the Ministry. 
the 495 defendants about civil law procedure to follow the court's procedures.

On 14 January 2002, the judges released a verdict which favored some parts of the plaintiff's lawsuit: declaring the disputed lands (HGU No. 1: 32.23 ha, HGU No. 2: 388.70 ha, and HGU No. 1: 46.55 ha) as belonging of the Plaintiff and the land occupation and cultivation by the defendants as unlawful act. This verdict dissapointed the defendants and their lawyers because they found that the law suit had not fulfilled any formal and material requirements of a proper lawsuit. However, no other action could be taken except to file an appeal to the High Court of Central Java. This appeal had been registered in the High Court ascase number 37/Pdt/2003/ PT.Smg. The Semarang High Court's verdict which was released on 26 May 2003 was not different from the District Court's verdict. It affirmed the decision of the District Court. Therefore, the peasants must launched the last effort to seek justice through the Supreme Court in Jakarta. Registered in case number 1743 K/Pdt/2004, this case was finally decided on 7 November 2006.

The Jakarta-based Supreme Court revoked the decision of the Semarang High Court. It revoked the High Court's verdict by rejecting all of the plaintiff's lawsuits and stated that the PTPN IX had no legal standing to file anylawsuit. The Supreme Court accepted the defendants' appeal. Actually the decision of the judges was not really clear related to the peasants' claim over the plantation lands which became the main point of the PTPN IX lawsuit. As result, each party interpreted the meaning of the verdict according to each own interpretation. Besides that, this Supreme Court's verdict document had just been received by the peasants in the 2011 or six years too late.

\section{Recent Condition on the PTPN IX Case}

After the Supreme Court announced the result of the land dispute, the situation at the grassroot level has not yet returned back into normal. During 2011-2014, the PTPN IX tried for four times to re-occupy the peasants' lands. Their first illegal action occured in Pencar Hamlet, Kaliputih Village. Some workers of the PTPN IX rode in a truck to the village and planted rubber seedlings on the peasants' lands. This action was followed a day later by another planting and cutting action in the same village in Munggang area, Pencar Hamlet; but no one remembered the date and year of the action. The second action brought more laborers than those in the first action. This re-occupation attempt happened before the planting season of the peasants. Some peasants tried to restrain the action, but their effort failed. In the second action, the hired thugs planted rubber at least on 10 ha of the peasants' lands. Following the second action, the third action was done by approximately 30 workers in Kesruk area, Kaliputih village. These workers dug some holes over the peasants' lands to be planted by rubber seedlings. The fourth action was done in Pencar Hamlet where the PTPN IX's workers rode in three trucks into the hamlet to occupy the lands. This time, the re-occupation attempt could be stopped by the peasants because the peasants involved the police to stop the company's workers'action. ${ }^{23}$

In Kalidapu Hamlet, the PTPN IX had evicted around 20 peasants from their reclaimed/cultivated lands. The PTPN IX planted rubber seedlings after cutting down thousands of sengon (silk) trees on 8 ha of the peasants' lands. This action inflicted losses in access of the peasants to their lands which had been reclaimed/cultivated since 1998.

\footnotetext{
${ }^{23}$ Interviews with N, G, J, S, and some other peasants from Banyuringin Village, Kendal District, 26 July 2014.
} 
After several re-occupation attempts by the PTPN IX, the peasants in the conflict area were still cultivating their lands as usual. Mostly the peasants planted silk trees and crops. There were no other action until September 2014 when peasants received a letter from the PTPN IX. This is a notification letter addressing the Kendal District Police to notify the latter that the PTPN IX will plant trees and put stakes over the disputed lands on 4 October 2014. This action would be done by 1,500 workers. $^{24}$ Moreover, the PTPN IX put up a banner on the disputed land to urge the peasants to cut the peasants' sengon/albasia trees. ${ }^{25}$

\section{Analysis on the State Responses to the Land Cases}

The forms of state responses in the two cases are criminalizing the peasants, accomodating the complaints, forming a conflict resolution team, facilitating negotiations, deploying the police (Brimob) on the plantation land, deploying the thugs, and using the Court to evict the peasants.

However, the state's responses against the peasants' resistance are always changeable and influenced by some external factors. Each of the state apparatuses at all levels of the executive, legislative, and judicative has its own action, policy, or decision which is not always correlated to one another. This demonstrates that the state is not a compact and bounded institution. The responses of state apparatuses like the Governor and the National Land Agency of Central Java show their intention to protect the interest of the companies (PT Tratak and PTPN IX) in occupying the plantation lands. But the other state apparatus at executive level, like the Batang Regent and the Supreme Court in judicative level have different decisions. They can not be categorized as institutions which facililitate the interest of the dominant parties (the companies).

The state responses do not stand alone but always related to circumstances at the local level such as the existing/the solidity of the peasants local organization, another government institution response, the non-litigation procedures that have been taken, the legal status of the plantation, the civil society support, the condition of the plantation/the plantation land right holder, and the existing regulation on abandoned land. In the case of PT Tratak, the circumstances over the land conflict such as the strength/solidity of the local peasant organization and the abandoned land have influenced the peasants to reclaim the land and obtain support both from the National Land Agency and other government institutions to revoke the plantation company's right of commercial cultivation. This condition is supported by the peasants' network like the peasant organization at the district level (Omah Tani) and public interest lawyers who assisted them voluntary through non-litigation and litigation procedures like negotiations and lobbies.

In the case of the PTPN IX, circumstances over the land conflict also influence the peasants to acquire the land. The land conflict of the state plantation company is more difficult to be solved than that over plantation land owned by private companies. Even though the peasants obtain support from the local Parliament at

24 PTPN IX, "Aksi FSPBUN Ambil Alih Lahan PTPN IX," http://ptpnix.co.id/aksi-fspbun-ambil-alih-lahan/, accessed 16 September 2014; Suara Merdeka, "Warga Singorojo Kembalikan Lahan Perkebunan," http://berita.suaramerdeka.com/smcetak/warga-singorojo-kembalikan-lahan-perkebunan/, accessed 16 September 2014.

25 Radar Pekalongan, "Bupati Minta Agar SP dan Warga Tahan Diri," http://www.radarpekalonganonline. com/42210/bupati-minta-agar-sp-dan-warga-tahan-diri/, accessed 6 May 2015. 
the beginning, the plantation lands of the PTPN IX are categorized as state assets which can only be excluded from the plantation area by the Ministry of State Owned Enterprises' permission. The PTPN IX's right of commercial cultivation No. 82/HGU/ DA/1982 had expired on 31 December 2005 and has not yet been extended by the National Land Agency. Whereas the decision of the Supreme Court has been released and should become consideration for the National Land Agency to take some steps towards land redistribution. The Deputy II of the National Land Agency said that if the land was owned by the PTPN IX, it was categorized as state asset which is not under the National Land Agency authority to be solved. If this is related to state asset, the relevant institutions should be the Ministry of State Owned Enterprises and the Ministry of Finance. The land could not be released without the Minister of State Owned Enterprises permit. ${ }^{26}$ Furthermore he said that if the Supreme Court stated in the decision that the land must be excluded from the plantation, it would be easy for the National Land Agency to execute the land because the Minister of State Owned Enterprises will follow the Supreme Court instruction. The procedure would be like this: the Minister of State Owned Enterprises will report to the Minister of Finance about the release of asset and after that the National Land Agency can follow up the recommendation.

Meanwhile, the recent situation at the village shows that the conflict escalated after the Supreme Court released the verdict in 2011 and so far the government never tried to stop the violence. The situation is getting worse when the strength of the peasants' organization (Kerukunan Warga Kaliputih/KWK) was declining.

The state's response is always correlated with the fulfillment of peasants' rights to land. But in these cases, the state's response does not always correspond with the fulfillment of the peasants' rights to land. There are some factors related to the failure of the state to fulfill the peasants' right to property/right to land. Firstly, there is no recognition to the peasants' right to land. In the land case of PT Tratak, instead on giving the lands to the peasants, the state grabbed lands which had been cultivated by the peasants since the Indonesian independence (1945) during the 1957 nationalization period. The eviction of the peasants at that time affected their livelihood; they became landless. Likewise, the similar condition also occured in Kalidapu Hamlet/Kaliputih Village. The peasants' lands were grabbed by the state to become state plantation company. The land confiscation closes the opportunity for the peasants to get land certification. Secondly, during the ongoing land conflicts (19982014), the government responses show its ignorance to its obligation to protect and to respect the peasants' right to land. The state fails to stop violence that occured over the plantation land conflict area. On the contrary, the government is eager to accuse or criminalize the peasants (in PT Tratak case) for occupying lands. These "no recognition policy" on land rights have been continued later when the peasants must follow the court's hearings as defendants when the judges ignore the peasants' right to land as their consideration before releasing the courts' verdicts.

\section{International Human Rights Instruments on the Right to Property}

The violation of land rights has spread to other violation of rights such as right to food, right to housing, right to education, right to health, right to water, freedom from fear, freedom of expression, and right to life. Despite land rights' fundamental

${ }^{26}$ Interview with Doddy Imron Cholid, Deputy V of the National Land Agency, 28 October 2014. 
value and land conflicts' impact to all aspects of human life, international human rights law such as UDHR, ICCPR, and ICESCR do not provide particular instrument for land rights. Rarely scholars have discussed about the weaknesses of the international human rights laws on land rights. Wickeri and Kalhan, ${ }^{27}$ for example, examine land rights as a cross-cutting issue that can be found in some other kinds of rights like housing, indigenous peoples, women, and right to food.

The international human rights laws does not specifically mention about the right to land. However, right to land was categorized into right to property which is stated in some treaties. Article 17 of the Universal Declaration of Human Rights: (1) Everyone has the right to own property alone as well as in association with others, and (2) No one shall be arbitrarily deprived of his property. Moreover the right to property had also been mentioned mainly in Article 26 ICCPR. It is also stated in other relevant articles, that is Article 1 and 27 ICCPR.

Commentary of the Charter of Fundamental Rights of the European Union ${ }^{28}$ explained that the provision of the first paragraph of Article 17 UDHR has been taken over in Article 5 al. d (v) of the International Convention on the Elimination of All Forms of Racial Discrimination (1965), being thus listed among civil rights.

However, there are no equivalent provisions in the International Covenant on Civil and Political Rights 1966 and the International Covenant on Economic, Social and Cultural Rights 1966. This omission in both UN Covenants may be due to the serious ideological controversies about the right to property at that time. The only provision corresponding to the second paragraph of Article 17 of the Charter can be found in ICESCR, Article 15:

\section{The States parties to the present Covenant recognize the right of everyone:}

(...)

c) To benefit from the protection of the moral and material interests resulting from any scientific, literary or artistic production of which he is the author.

The right to protection of intellectual property as mentioned in point $\mathrm{c}$ has been included in the category of cultural rights. As a consequence, the Human Rights Committee, acting on the basis of the Optional Protocol to ICCPR, is not able to examine alleged violations of the right to property. Nevertheless, the HRC recognizes - on the basis of Article 26 - the right to non-discrimination in the matter of property. The summary of the corresponding provisions clearly shows the disputed nature of the right to property in other international instruments.

The right to property also has been mentioned in other relevant instruments like Articles 15 and 16 CEDAW, ILO 107 concerning the Protection and Integration of Indigenous and Other Tribal and Semi-Tribal Populations in Independent Countries, ILO 169 concerning Indigenous and Tribal Peoples in Independent Countries, and United Nation Declaration on the Rights of Indigenous Peoples.

27 E. Wickeri and A. Kalhan. "Land Rights Issues in International Human Rights Law." Malaysian Journal on Human Rights, Vol. 4, No. 10. 2010; Drexel University Earle Mack School of Law Research Paper ; Fordham Law Legal Studies Research Paper No. 1921447. Accessed 24 August 2014. http://ssrn.com/ abstract $=1921447$.

${ }^{28}$ EU Network of Independent Experts on Fundamental Rights, The Commentary of the Charter of Fundamental Rights of the European Union, (Network of Independent Experts on Fundamental Rights, 2006), p. 163, http://ec.europa.eu/justice/fundamental-rights/files/networkcommentaryfinal en.pdf, accessed 22 May 2015. 


\section{Analysis on the Legal Basis of Abandoned Land and State-Owned Enterprises}

\section{A. Law Regarding Abandoned Land}

Law No. 5 Year 1960 regarding Basic Agrarian Law and Government Regulation No. 40 Year 1996 regarding Right of Commercial Cultivation, Right of Use of Structures, and Right of Use contain some provisions on the right of commercial cultivation. Article 12 of the Government Regulation No. 40 Year 1996 stipulates that right of commercial cultivation's holder must follow the provisions. For example, they are not allowed to rent their land to other party nor abandon their land. Likewise, the right holder must fulfill some requirements to obtain right of commercial cultivation. If there is administrative flaw committed during the process of obtaining right of commercial cultivation committed by the National Land Agency, the right of commercial cultivation can be withdrawn by the National Land Agency or by Court. ${ }^{29}$ In the case of PT Tratak, the plantation land has been abandoned for many years but the National Land Agency did not take any legal action to warn the company. This situation would be persisted if the peasants did not file any complaint to the National Land Agency.

The first national regulation on abandoned land was the Government Regulation No. 36 Year 1998 regarding Control and Utilization of Abandoned Land. According to this regulation, the government can investigate/identify the right of commercial cultivation over land when the right holder neglects the land. The identification can be based on people's/peasant's complaint over abandoned land. After receiving complaint, the government will investigate/identify the abandoned land. If the land has characteristics as "abandoned", the government issues a warning to the right holder/company to utilize the land. The warning is valid for one year. If the right holder does not obey the government's direction, the second warning will be issued. Likewise, when the second warning is ignored, the government will give the third warning. Overall, it takes three years for the government to give warning to the right holder/company to utilize the abandoned land. If the right holder keeps ignoring the government's third warning, the government can declare the land as "abandoned". However, before the decision can be made, the government will give a chance to the right holder to hand over the land through auction. When new right-holder is definite, the former right holders will receive compensation for all expenses that they spent during obtaining the land rights including the physical building that may be built on the abandoned land. In this case, all the compensation will be paid by the new land right holder. ${ }^{30}$

This regulation was rarely used to respond to cases on abandoned land because of the long procedure that must be followed to pronounce land as "abandoned". In addition, the unresponsive government in following up peasants' complaint on abandoned lands resulted in uncertainty of the abandoned land cases solution. ${ }^{31}$ Some

${ }^{29}$ Indonesia (1), Peraturan Menteri Negara Agraria/ Kepala Badan Pertanahan Nasional tentang Tata Cara Pemberian dan Pembatalan Hak Atas Tanah Negara dan Hak Pengelolaan [Minister of Agrarian/Head of National Land Agency Regulation regarding Procedure of Giving and Revoking Right of State Land and Right of Management], Permen No. 9 Tahun 1999 [Regulation No. 9 Year 1999], art. 104.

30 Indonesia (2), Peraturan Pemerintah tentang Penertiban dan Pendayagunaan Tanah Terlantar [Government Regulation regarding The Control and Utilization of Abandoned Land], PP No. 36 Tahun 1998 [Government Regulation No. 36 Year 1998], art. 15.

31 The size of abandoned lands throughout Indonesia is 7.20 million ha out of which approximately 1.80 million ha lands are the under companies' HGU (Mulyanto, 2012). 
complaints have been filed by the peasants to the National Land Agency of Central Java to take action (revocation of HGU) around abandoned lands in Central Java. However, there was no action conducted by this institution, such as investigation/identification and issuance of warning to follow-up the peasants' complaints. ${ }^{32}$

In 2010, the government renewed regulation on abandoned land through Government Regulation No. 11 Year 2010 regarding The Control and Utilization of Abandoned Land. This regulation has been followed by its implementing regulations: the National Land Agency Regulation No. 4 Year 2010 regarding the Procedure of Regulating Abandoned Land which has been amended with the National Land Agency Regulation No. 9 Year 2011 concerning the Procedure of Regulating Abandoned Land. Different from the first regulation, this regulation excluded the government's lands as the possible object of abandoned land. Moreover, this regulation requires only three months to declare land as "abandoned". After identifying lands which are categorized as abandoned, the government warns the right holder to utilize the lands within one month after receiving the warning letter. Likewise, the second warning letter will be sent to the right holder if the right holder ignores the first warning letter. If the right-holder does not follow direction in the second warning letter in one month, the government will send the third warning letter. ${ }^{33}$ Finally, Head of the National Land Agency Province will propose the Central National Land Agency to decide land as abandoned after the right holder ignores the third warning letter. In order to verify data on the abandoned lands, the National Land Agency will form a committee called Committee $\mathrm{C}$ which consists of National Land Agency Province, district land office, local government, and relevant institutions. ${ }^{34}$

\section{B. Law Concerning State-Owned Enterprises}

The Supreme Court's decision is final because the PTPN IX as a Plaintiff does not take another legal action (such as Peninjauan Kembali/Review of the Court's decision). However, the Court's decision is difficult to be executed because it only decides that the Plaintiff's lawsuit "cannot be accepted". The legal status or ownership of the disputed lands is not decided. Likewise, the plantation company cannot repeat launching legal action such as filing another lawsuit to the peasants for reclaiming the plantation lands. As such, the peasants find obstacle to enforce the execution of the Court's decision because of the unspecified meaning of the verdict. Every party tries to interpret the meaning of the verdict as it does not state that the company's control over the land is unlawful. Therefore, the opportunity to withdraw the company's right of commercial cultivation appears during the end period of the right of commercial cultivation.

Since 31 December 2005, the right of commercial cultivation had ended and the National Land Agency does not extend the right of commercial cultivation. According to Article 17 (2) Law No. 40/1996, if there is no extension of the right of commercial

32 Siti Rahma Mary Herwati and Dody Setiadi, Memahami Hak Atas Tanah dalam Praktek Advokasi (Semarang: LBH Semarang, 2005), p. 169.

${ }^{33}$ Indonesia (3), Peraturan Pemerintah tentang Penertiban dan Pendayagunaan Tanah Terlantar [Government Regulation regarding The Control and Utilization of Abandoned Land], PP No. 11 Tahun 2010 [Government Regulation No. 11 Year 2010], art. 8.

${ }^{34}$ Indonesia (4), Peraturan Badan Pertanahan Nasional tentang Tata Cara Pengaturan Tanah Terlantar [National Land Agency Regulation regarding The Procedure of Regulating Abandoned Land], Peraturan BPN No. 4 Tahun 2010 [Regulation No. 4 Year 2010], art. 9. 
cultivation, the plantation land becomes state land. Hence, according to Article 18 (1) Law No. 40/1996, the right holder must dismantle the buildings and goods over the plantation land and deliver land and plants on the plantation land to the state.

Up to now, those provisions are never realized. The PTPN IX is still occupying, controlling, and planting, and at the same time the plantation workers are intimidating the peasants. However, the company uses the legal status as a state plantation to occupy the land without being interrupted by the state. The National Land Agency contends that even though the company's right of commercial cultivation has ended, the land still belongs to the state as state assets.

The PTPN IX is a state plantation company in the form of Incorporated Company (Perseroan Terbatas/Persero) which follows Law No. 19 Year 2003 regarding StateOwned Enterprises and Law No. 40 Year 2007 regarding Incorporated Company. According to Article 1 paragraph 1 of Law No. 19 Year 2013, state-owned enterprises is a company whose total or most parts of its assets are owned by the state through direct investment derived from separated state assets. Article 4 paragraph 1 of this regulation mentioned that state-owned enterprises' assets are and derived from the separated state assets. The elucidation of this article explain that the separated state assets means separation of state assets from state budget (Anggaran Pendapatan dan Belanja Negara/APBN) to be invested in the company. Henceforth, the state assets is not managed based on state budget system but based on the good principles of company. Some people argue that the company' assets should not be categorized as state assets because they are derived from the separated state assets. On the contrary, most state officials still argue that the PTPN IX's assets are the state's assets. The debate is still ongoing but the argument that the PTPN IX's assets are state assets is more acceptable.

The position/legal status of the PTPN IX related to giving and extending the right of commercial cultivation should not different with other company especially private company. In addition, Basic Agrarian Law No. 5 Year 1960 and Government Regulation No. 40 Year 1996 do not differentiate the legal statuses of company (state or private company) before it delivers land to the state in case their right of commercial cultivation ends. The state's response to the PTPN IX's action to occupy the land demonstrates that the state breaches the law and commits citizen and human rights violation by letting the PTPN IX's workers intimidating the peasants.

In order to withdraw the company's right of commercial cultivation which has ended in 2005, the peasants must take another action after the Supreme Court releases its decision. The peasants must file an application to the National Land Agency to reject the extension of the right of commercial cultivation. At the same time, the peasants can ask the Minister of State-Owned Enterprises to approve the release of the PTPN IX's land.

Release of immovable assets can be done based on the Minister of State-Owned Enterprises Regulation No. PER-02/MBU/2010 regarding Procedure of Write-off and Transfer of Ownership of State-Owned Enterprises' Fixed Assets in conjunction with the Minister of State-Owned Enterprises Regulation No. PER-06/MBU/2010 regarding Amendment of the Minister of State-Owned Enterprises Regulation No. PER-02/MBU/2010. This procedure can be carried out by Directors of PTPN by filing an application on the release of the company's assets to the Minister of State-Owned Enterprises. Article 15 of the regulation states that the Directors of the state-owned enterprises must get approval from the Board of Commissioners/Board of Trustees 
or General Meeting of Shareholders/the Minister to transfer fixed assets according to the state-owned enterprises' article of association. Whether the application is approved or not approved depends on the Minister's decision himself. However, reasons to release the company's assets must be based on the Minister of StateOwned Enterprises Regulation No. PER-02/MBU/2010. If the assets are released for the public interest, the company will receive compensation. ${ }^{35}$

The authors contend that in the case of the PTPN IX, both the approval of the Minister of State-Owned Enterprises and the will of the PTPN IX's management are difficult to obtain considering that the company's resistance against the peasants. The situation will be different if the Supreme Court's decision clearly states that the PTPN IX's land occupation is unlawful. The author contends that this situation is unfair because the peasants as victim must fight their own way to reclaim their land rights. Whereas the National Land Agency as the responsible institution that releases the company's right of commercial cultivation or other government institutions like the Governor or the Parliament do nothing to respond to the company's unilateral actions. The National Land Agency should release a letter concerning the utilization and use of the land to the Governor, and after that the Governor can follow-up the letter by sending a letter to the Minister of State-Owned Enterprises to release the assets. If all processes are commenced by these institutions, the PTPN IX will process the release after the Directors get approval from the Minister.

The author contends that the release of the PTPN IX' assets will never materialize if those institutions do not take action to commence the process and if the PTPN IX's management do not agree to release the assets. What had happened in these cases was a reflection of what Stocks ${ }^{36}$ found in South American countries with "superior" legal framework for indigenous land tenure, ${ }^{37}$ i.e., Brazil, Colombia, Bolivia, and Peru. In Brazil, for example, after the 1988 Constitution's Article 231 held that Brazil's indigenous people are the original and natural owner of Brazilian land with land rights' having precedence over other land rights (and 1988's Article 67 ordering demarcation of all terras indigenas or TIs), President Cardoso ordered through Presidential Decree 22 to demarcate all TIs by 1993. While only 291 out of 559 terras indigenas demarcated by 1993, many powerful sectors of society with material interests in the natural resource in the TIs complained to politicians about the constitutional measures and decrees that supported and regulated them. In 1996 President Cardoso issued Decree 1775 that gave "states, municipalities, and individuals" the rights to contest demarcations at any point in the process until the land is fully registered (Stocks 2005, p. 92). As a result, out of 559 terras indigenas identified at that time in Brazil, 344 were opened for contestations.

In Colombia, the legalized [indigenous] "reserves" (resguardos) were integrated

35 Indonesia (5), Peraturan Menteri Badan Usaha Milik Negara tentang Tata Cara Penghapusbukuan dan Pemindahtanganan Aktiva Tetap Badan Usaha Milik Negara [Minister of State-Owned Enterprises Regulation regarding The Procedure of Write-off and Transfer of Ownership of State-Owned Enterprises' Fixed Assets], PER-02/MBU/2010, art. 11.

36 See Anthony Stocks, "Too Much for Too Few: Problems of Indigenous Land Rights in Latin America," The Annual Review of Anthropology Vol. 34 (October 2005): 85-104, doi: 10.1146/annurev.anthro.33.070203.143844..

37 See Ortiga R. Roldan, Models for recognizing Indigenous land rights in Latin America, (Washington, D.C.: The World Bank, 2004). Roldan divided Latin America into three kinds of countries: with "superior" legal frameworks for indigenous land tenure (Bolivia, Brazil, Colombia, Costa Rica, Panama, Paraguay, and Peru), "in progress" (Argentina, Guatemala, Honduras, Mexico, Nicaragua, and Venezuela), and "deficient" (the rest of Latin American countries). 
under the new 1991 Constitution as Inalienable Indigenous Territorial Entities (ETIs) as part of indigenously governed political/cultural/economic entities in geographic space that include one or more resguardos, as well as other lands (Stocks 2005, p. 93). Coexistence of private property with communal property had worried some observers that unacceptable degrees of social stratification may ensue as mestizos or affluent indigenous families gain land and power (Field 1996). Padilla (1996) even claimed that the state has inserted a "Trojan horse" into the indigenous movement by making indigenous territories part of the state political apparatus. In Bolivia (a country where only 3 percent of its population living in the lowlands), the constitutional change in 1994 and Law 1715 of 1996 introduced the legal figure of tierras communitarias de origen (original community lands or TCOs) and allowed indigenous peoples and groups of communities to claim a territory jointly (Stocks 2005, p. 94). The main criticism against this Law 1715 was that although it allowed for titling territories rather than communities, the process of cadastral studies (named saneamiento or cleansing) prioritized all other claimants before indigenous people (Colchester et al. 2001).

In Peru, the 1993 Constitution revoked the inalienability of indigenous lands and reasserted the state's absolute control and ownership of natural resources (Dean 2002).

Back to the two cases in Java, a President at his last 16 months of second term of presidency suddenly launched a land redistribution program (Reforma Agraria) in January 2007 to redistribute 1.10 million hectares of forest lands under the authority of the National Land Agency, 8.15 million hectares under the Ministry of Forestry and other 7.30 million of abandoned lands. The parallel of this Reforma Agraria to the Latin American cases appears as the unclear targets or definitions of the "redistribution" of the "abandoned" or "unused" lands. Turning into a double-edged sword as everyone could interpret the land "redistribution" to one's own interests, the program became a means to allow every actor-indigenous groups, the peasantries, private/public companies, municipalities, state-based companies, etc-to join the scramble of the no-man's lands. Thus, a Paradox appeared that when the chaotic situation where the states were futile to handle the situation, the programs apparently settled to favor or at least to open chances for the poor-indigenous groups, peasantries, the landless, etc-were hijacked by other stronger counter-claimants. The new forms of power relations offered by this Stocksian Paradox are very important to offer clues as to why the peasants and landless farmers in Java's little hamlets have become so distressed by cross-firing exertion of so many kinds of forms (thugs, legal, courts, private companies, state-run companies, state's apparatuses, etc).

This Paradox opens the relevance of typical criticisms ${ }^{38}$ in Latin American cases against the opening of other forms of land rights onto the indigenous (or "abandoned" land in economic terms) to the similar cases in Java. The conceptualization of Java cases throughout the lenses of "too much [land] for too few [actor]" as offered by Stocks becomes possible and useful to explain the failure of the poor peasantries to grab [their] chances.

38 For the Brazilian case, the main criticisms were claims that real motivation for the Presidential Decree 1775 was to open the terra indigenas for natural resource exploitation. Padilla's (1996) claimed in the Colombian case that the state had pushed a "Trojan horse" into the indigenous movement by turning indigenous territories part of the state political apparatus. In the Bolivian case, many pointed that the process of cadastral studies (cleansing or saneamiento) prioritized all other claimants before indigenous people. In the Peruvian case, Newing (2004) reported that some governments are wary of creating communal reserves that would tie up resources that could be given out in concession). 


\section{Conclusion (and Recommendation)}

This study shows that the peasants' land rights are still far-reaching to be fulfilled. The "hiccups" taking place when the Ministry of Agrarian and Spatial Planningpolitically forced to "continue" the decisions of the previous government'sredistributed some plots of confiscated land back to the peasants in some villages were just to a road show covering few hundreds hectares of land out of the promised 16.55 million hectares. There are some factors related the failure of the state to fulfill the peasants' right to land. First, there is no recognition to the peasants' right to land. In the land case of PT Tratak, instead on giving the lands to the peasants, the lands which had been cultivated by the peasants after the Indonesian independence were grabbed by the state during the nationalization period. The eviction of the peasants at that time brought them into landlessness. Likewise, the similar condition also occurred in Kalidapu Hamlet/Kaliputih Village. The peasants' lands were grabbed by the state to become state plantation company. During the ongoing land conflicts (1998-2014), the government responses show the ignorance of its obligation to protect and to respect the peasants' right to land. It has been shown by the government's failure to stop violence occurring around the plantation land conflict area. In contrast, the government is eager to accuse/criminalize the peasants (in PT Tratak case) for occupying lands. This no recognition policy has been continued to next days when the peasants must follow the Court procedure as the defendants where the Courts failed to consider the peasants' right to land as their consideration before releasing the courts' verdicts.

Secondly, there is no clear action from the government to execute the Courts' verdict. In the case of PTPN IX, although the plantation' right of commercial cultivation has ended in the 2005 and the supreme court's verdict had rejected the PTPN IX's lawsuit, the execution of the court's verdict seems hard to be implemented because the plantation lands are included as state assets. This research finds that the peasants' land rights claims are not totally recognized by the state even though the peasants won the land disputes in Courts.

In these cases, the peasants have positioned the state as a center to resolving the land conflicts. Nevertheless, the intention has been hampered by the state's selfinterest in defending the plantations assets. This Stocksian Paradox occurs when the "Reformasi" opens political and legal opportunity for the peasants to claim their land rights, but it is also used by the other parties like the state and the companies as "door" to defend their old vested interests. Stocks ${ }^{39}$ found a deep paradox in South American countries when he saw that the increasing debility of states in the central exercise of power-a defect directly correlated with neoliberal decentralization-provides political openings not only for indigenous people to contest the state but also for all social sectors with similar desires. In Stocks' own words, "As political space is opened for indigenous people, counter-claimants to their land and resources multiply". In Central Java, this Stocksian Paradox appears in a more complicated version where the state has turned itself into one of these counter-claimants to the land and resources of indigenous or peasantries of Central Java. If the strong institutional support from the state seems critical to make differences among South American cases, ${ }^{40}$ the strong support from the state in Central Java case turns into an increasingly impossible factor given this deep conflict of interest.

\footnotetext{
${ }^{39}$ Stocks, op.cit., p. 97.

40 Ibid.
} 
Examining the two land cases, the researchers contend that the robust civil society is the prerequisite for the peasants to reclaim land rights that have been acknowledged by the Constitution and the International Conventions. The Legal Aid Institute, public interest lawyers, and students play a significant role in assisting the peasants to obtaining land rights/defending their property rights. The peasants' resistance against plantation companies and government's abusive policy on land rights is a long struggle that entails endurance until the goal is achieved. The two cases demonstrate that even though the Courts have decided on the peasants' favor over the companies, the fulfillment of the peasants' rights to land is still not realized. Hence, the future challenge for the peasants and their supporters is to urge the state to fulfill the rights.

In addition, the authors also find that the main problem around the failure of the state to realize the fulfillment of the peasants' rights to lands is the policy on the procedures to release "state asset". The Stocksian Paradox-cum-conflict of interest has been deeply entrenched into agricultural and land policy in Indonesia. In the PTPN IX case, the fulfillment of the peasants' land rights will not be reached if the government refuses to pay attention to it. Therefore, it is necessary for the government to withdraw or improve the procedures on the releasing of state plantation companies' immovable assets back to "state lands".

\section{Bibliography}

\section{Legal Documents}

Administrative Court of Jakarta. "Decision No. 25/G/2013/PTUN-Jkt."

General Court of Kendal. "Decision No. 16/Pdt.G/2000/PN Kdl.”

High Court of Central Java. "Decision No. 37/Pdt/2003/PT. Smg."

Indonesia. Peraturan Menteri BUMN tentang Perubahan atas Peraturan menteri Negara BUMN No. PER-02/MBU/2010 [Minister of State-Owned Enterprises Regulation regarding Amendment of the Minister of State-Owned Enterprises Regulation No. PER-02/MBU/2010]. Peraturan Menteri BUMN No. PER-06/ MBU/2010 [Regulation No. PER-06/MBU/2010].

Indonesia. Peraturan Menteri BUMN tentang Tata Cara Penghapusbukuan dan Pemindahtanganan Aktiva Tetap Badan Usaha Milik Negara [Minister of StateOwned Enterprises Regulation regarding Procedure of Write-off and Transfer of Ownership of State-Owned Enterprises' Fixed Assets]. Peraturan Menteri BUMN No. PER-02/MBU/2010 [Regulation No. PER-02/MBU/2010].

Indonesia. Peraturan Pemerintah tentang Penertiban dan Pendayagunaan Tanah Terlantar [Government Regulation regarding The Control and Utilization of Abandoned Land]. PP No. 11 Tahun 2010 [Government Regulation No. 11 Year 2010].

Indonesia. Undang-undang tentang Badan Usaha Milik Negara [Law regarding StateOwned Enterprises]. UU No. 19 Tahun 2003, LN No. 70 Tahun 2003 [Law Number 19 Year 2003, SG No. 70 Year 2003].

Indonesia. Peraturan Pemerintah tentang Hak Guna Usaha, Hak Guna Bangunan, Hak Pakai Atas Tanah [Government Regulation regarding Right of Commercial Cultivation, Right of Use of Structures, and Right of Use]. PP No. 40 Tahun 1996 [Government Regulation Number 40 Year 1996].

Indonesia. Undang-undang tentang Peraturan Dasar Pokok Agraria [Law regarding 
Basic Agrarian Law]. UU No. 5 Tahun 1960, LN No. 104 Tahun 1960 [Law Number 5 Year 1960, SG No. 104 Year 1960].

Indonesia. Undang-undang tentang Perseroan Terbatas [Law regarding Incorporated Company]. UU No. 40 Tahun 2007, LN No. 106 Tahun 2007 [Law Number 40 Year 2007, SG No. 106 Year 2007].

Supreme Court of Republic Indonesia. "Decision No. 1743 K/PDT/2004."

UN General Assembly. Universal Declaration of Human Rights. 10 December 1948, 217 /A(III). Available at http://www.refworld.org/docid/3ae6b3712c.html. Accessed 24 August 2014.

\section{Books}

Benedek, W. Ed. Understanding Human Rights: Manual on Human Rights Education. Graz: European Training and Research Centre for Human Rights and Democracy (ETC), 2012.

EU Network of Independent Experts on Fundamental Rights. The Commentary of the Charter of Fundamental Rights of the European Union. Network of Independent Experts on Fundamental Rights, 2006. http://ec.europa.eu/justice/ fundamental-rights/files/networkcommentaryfinal_en.pdf. Accessed 22 May 2015.

Herwati, Siti Rakhma M., and Dody Setiadi. Memahami Hak Atas Tanah dalam Praktek Advokasi. Semarang: LBH Semarang, 2005.

Roldan, Ortiga R. Models for recognizing Indigenous land rights in Latin America. Washington, D.C.: The World Bank, 2004.

\section{Articles}

Aspinall, Edward. "Transformation of Civil Society and Democratic Breakthrough" in Civil Society and Political Change in Asia, Expanding and Contracting Democratic Space. Edited by Muthiah Alagappa. California: Stanford University Press, 2004.

Dean, B. "State power and indigenous people in Peruvian Amazonia: a lost decade, 1990-2002." In The Politics of Ethnicity: Indigenous Peoples in Latin American States. Edited by D. Maybury-Lewis. Cambridge, MA: Harvard University Press, 2002.

Field, Les W. "State, Anti-State and Indigenous Entities: Reflectioins Upon a Páez Resguardo and the New Colombian Constitution." Journal of Latin American and Caribbean Anthropology Vol. 1 Issue 2 (March 1996): 98-119. DOI: 10.1525/ jlca.1996.1.2.98.

Rachman, Noer F. "The Resurgence of Land Reform Policy and Agrarian Reform in Indonesia," (A dissertation submitted in partial satisfaction of the requirements for the degree of Doctor of Philosphy in Environmental Science, Policy and Management, University of California, Berkeley, 2011).

Stocks, Anthony. "Too Much for Too Few: Problems of Indigenous Land Rights in Latin America." The Annual Review of Anthropology Vol. 34 (October 2005): 85-104. DOI: 10.1146/annurev.anthro.33.070203.143844.

Wickeri, E., and Anil Kalhan. "Land Rights Issues in International Human Rights Law." Malaysian Journal on Human Rights Vol. 4, No. 10. (2010); Drexel University Earle Mack School of Law Research Paper; Fordham Law Legal Studies Research Paper No. 1921447. http://ssrn.com/abstract=1921447. Accessed 24 August 2014.

\section{Websites}


Colchester, M., et.al., A Survey of Indigenous Land Tenure: a Report for the Land Tenure Service of the Food and Agriculture Organization. http://www.forestpeoples. gn.apc.org.

Huma Win. "HumaWin." https://www.humawin.org. Accessed 10 September 2014.

Kendalonline. "Tanaman tumpangsari dibabat PTPN IX Warga Banyuringin protes." http://www.kendalonline.net/2007/04/10/tanaman-tumpangsari-dibabatptpn-ix-warga-banyuringin-protes/. Accessed 13 September 2014.

Komnas HAM. "Catatan HAM 2012 dan Rekomendasi. Saatnya Merajut Toleransi dan Kohesi Sosial." http://www.komnasham.go.id/siaran-pers/catatan-ham2012-dan-rekomendasi. Accessed 16 May 2015.

Komnas HAM. "Pandangan Komnas HAM terhadap Situasi Hak Asasi Manusia Tahun 2013 dan Tantangan Pada 2014." http://www.komnasham.go.id/sites/default/files/ dokumen-siaran-pers/Catatan\%20Awal\%20Tahun\%20Komnas\%20HAM.pdf. Accessed 16 May 2015.

KPA. “Laporan Akhir Tahun KPA (19 December 2013).” http://www.kpa.or.id/wpcontent/uploads/2011/11/Laporan-Akhir-Tahun-2013-KPA final-release-19Des.pdf. Accessed 5 April 2014.

Newing, H., "Collaborative Wildlife Managemetn and Changing Social Contexts in Amazonian Peru." http://www.kent.ac.uk/anthropology/dice/research/peru_ management.html.

PTPN IX. "Aksi FSPBUN Ambil Alih Lahan PTPN IX". http://ptpnix.co.id/aksi-fspbunambil-alih-lahan/. Accessed 16 September 2014.

Radar Pekalongan. "Bupati Minta Agar SP dan Warga Tahan Diri." http://www. radarpekalonganonline.com/42210/bupati-minta-agar-sp-dan-warga-tahandiri/. Accessed 6 May 2015.

Suara Merdeka. "Warga Singorojo Kembalikan Lahan Perkebunan." http:// berita.suaramerdeka.com/sm cetak/warga-singorojo-kembalikan-lahanperkebunan/. Accessed 16 September 2014.

Suara Pembaruan. "Aparat Gabungan Hancurkan Rumah Warga di Siak." http://www. suarapembaruan.com/nasional/aparat-gabungan-hancurkan-rumah-wargadi-siak/51862. Accessed 27 March 2014. 